DOI: 10.20472/IAC.2018.935.041

\author{
ANTOINETTE ROELOFFZE \\ Tshwane University of Technology, South Africa
}

CARINA KLEYNHANS

Tshwane University of Technology, South Africa

\title{
CHALLENGES OF A WORK-INTEGRATED LEARNING PROCESS IN A HOSPITALITY DEPARTMENT
}

\begin{abstract}
:
Work-integrated learning in the hospitality industry provides learners with the opportunity to gain experience in a real world context. The hospitality industry is known to be a stressful industry with antisocial working hours, poor salaries and high expectations of consistent good service. Currently the Department of Hospitality Management is experiencing many challenges relaying to successful placement of students in industry and completion of the work-integrated learning segment of students. A well-established process is followed, but this process does not address all the issues as the attitude of students' attitude has changed. Generation-Y students as well as first-generation students have needs that differ from those of previous students. Tertiary education has to include preparation for work-integrated learning in the curriculum to enhance the work-integrated learning experience. Students who should take responsibility for their own learning during internship, should realise the importance of a positive attitude. A successful internship will only be achieved if the tertiary environment, students and industry form a positive partnership, with each partner contributing to a well-prepared student with relevant employability skills suited to the work environment.
\end{abstract}

\section{Keywords:}

Challenges, Hospitality Industry, Work-integrated learning

JEL Classification: 123 


\section{INTRODUCTION}

Work-integrated Learning (WIL) can be defined as an activity or can be described as a programme that integrates the academic learning of a course with its application in the workplace. These activities or programmes provide link by integrating the theory of a specific course with the practice. As work-integrated learning involves a partnership among students, educational institutions and employers, there will necessrily be specified responsibilities for each of the above-mentioned parties (Fleming, Martin \& Hughes, 2009; Jackson, 2015; Swart, 2014). The key strategy of work-integrated learning is to ensure that the challenges, as well as the expectations of all the above-mentioned role players, are met (Zhang, Yin, David, Xiong, \& Niu, 2016). The hospitality industry is a highly stressful industry, as it is labour-intensive and involves frequent rotations. Work overload and intensive contacts with customers (Tsaur \& Tang (2012), as well as anti-social working hours, part-time labour, low pay, a poor image (Davidson \& Wang, 2011) and emotional labour are factors (Chen, Sun, Lam, Hu, Huo \& Zhong, 2012; Duncan, Scott \& Baum, 2013; Tsaur \& Tang, 2012).

\section{LITERATURE}

There is a growing interest in transforming the hospitality workplace into a more effective learning environment (Beham, Kump, Ley \& Lindstaedt, 2010). Work-integrated learning can take many forms, with each one encouraging the learner to participate in authentic work practices and practise applying knowledge and skills in a real-world context (Jackson, 2015). A theoretical framework is required to underpin the WIL experience and support learning to enhance the efficiency of hospitality learning (Mather, McKay \& Allen, 2015). Technology is only one of many significant opportunities to explore new forms of learning in the academic and workplace environment (Beham et al., 2010). Usually the mission statement of the specific educational establishment will provide the general direction of aims, as well as the education niche and mandate of work-integrated learning. One of the aims of career-oriented education is to entrench a specific value system and attitude of a utilitarian nature peculiar to each career (Wessels, 2005:5). Many tertiary establishments have already recognised the need to adapt courses to make the material more relevant to the student's future employment opportunities by incorporating work-integrated learning. Industry-relevant skills, knowledge and problem-solving skills as well as soft skills, such as team building, are essential steps towards future leadership positions and potential employment of graduates (Pratt \& Hahn, 2016).

A number of studies done in Australia during the last 10 years, have raised concerns regarding the work-readiness of graduates. This readiness does not merely refer to the lack of subject knowledge, but rather to the graduates' employability skills. A Business Industry and Higher Education Collaboration Council (BIHECC) report indicates that the perception in the industry is that universities provide students with a strong knowledge base, but they do not have the ability to apply the knowledge meaningfully in the work environment. One of the recommendations is that more emphasis needs to be placed on work-integrated learning to develop employability skills in higher education (McLennan \& Keating, 2008).

The demand for hospitality management graduates, who are critical thinkers and citizens of the world, serves as a mandate for hospitality educators to provide more learning opportunities 
thereby compelling the industry to foster these attributes (Brown \& Schmidt, 2016). Workintegrated learning is instrumental in assisting learners to become job-ready. Not only does this build learner confidence in the workplace, it also provides learners with a better understanding of the nature of required industrial skills (Jackson, 2015:351) as well as allow them to develop realistic expectations about their future careers (Wang, Cai, Yang \& Qu, 2015). A workintegrated learning experience influences the intention to work in the hospitality industry (Siu, Cheung \& Law, 2012) while teaching coping strategies will reduce the cost for hotels who will not have to teach these skills (Wang, Cai, Yang \& Qu, 2015).

As education, research and innovation are key drivers for competitiveness, jobs, sustainable growth and social progress, it is important to promote and reinforce co-operation between educational institutions and the hospitality industry (Kelli, Mets, Jonsson, Pisuke \& Adamsoo, 2013). However, there is no guarantee that there will be effective engagement with concrete outcomes, even if there is dialogue between tertiary institutions and the hospitality industry. One reason could be that establishments in the hospitality industry have difficulty in understanding what tertiary institutions have to offer. Tertiary institutions on the other hand are faced with their own challenges in placing students in the industry. Constant changes in the industry, as well as in higher education, can be seen as problematic. This could make it hard to maintain the relationships that originally established that connection (Tudor \& Mendez, 2014).

\section{WORK-INTEGRATED LEARNING PROCESS}

While the hospitality industry and tertiary institutions are joint producers when it comes to workintegrated learning, although results may be completely different, it is imperative that tertiary institutions face challenges posed by work-integrated learning and adapt to find solutions to these challenges to ensure a more efficient process (Zhou, Tijssen \& Leydesdorff, 2016).

\section{Relationship between tertiary institutions and industry}

The aim of work-integrated learning as part of a hospitality management course curriculum is to assist the learner in making the transition from visualising and listening to performing the activities that have been taught. Tertiary institutions and industry should foster partnerships when the curriculum is designed so that all stakeholders benefit from the work-integrated learning experience (Jackson, 2015). It follows that tertiary institutions are not only obliged to keep pace with global trends and developments that will have an impact on the work-integrated learning of the learner, but also to keep up with the training of those skills required by the industry to ensure alignment with real-world needs (Swart, 2014).

To achieve proper work-integration learning in tertiary institutions, industry needs to adopt certain principles. These principles include adequate learner preparation prior to practice, proper support regarding training and supervision during the placement and meaningful assessment/reflection to form a bond between academic and practical training (Jackson, 2015).

The hospitality industry relies heavily on knowledge, consequently the knowledge of the learner will play a critical role in the economic growth of a country (Zhou, Tijssen, \& Leydesdorff, 2016). In the past the economy of a country was driven by physical capital rather than knowledge. Currently there is a growing interest in making the work-integrated learning environment more 
practice oriented. For the learner to gain knowledge in his/her specific field of study, he/she has to rely on support, guidance and skills of competent teachers and trainers. Finding these knowledgeable and skilled people can be difficult. Reasons for the lack of knowledgeable and skilled people could be that there are not enough people with expertise and/or that competency databases are often outdated due to lack of maintenance (Beham, Kump, Ley \& Lindstaedt, 2010).

\section{Characteristics of the Generation Y learner}

Generation $Y$ learners (born after 1980) are entering the hospitality industry and already making up a large proportion of the workforce. Millennials, Netgeners and the Internet Generation are a few of the terms that are used to describe members of this generation. Whatever name is given they have been born into an environment that is characterised by rapid changes. These are largely technological, especially changes regarding to communication (Jones, 2007). They are identified by with ubiquitous gadgets such as the iPod and cell phone, and digital pastimes namely web surfing, blogging and text-messaging. They were born into the era ripe with mobile (cell phones) phones, and devices linked to television, computers and more importantly, internet broadband technologies (Gorman, Nelson \& Glassman, 2004; Jones, 2007).

One challenge facing both to the Generation $\mathrm{Y}$ learners and employees is that they are loyal to their parents, friends and team-mates at work, but not necessarily loyal to brands and their employers (Bately \& Woodbridge, 2007). According to research the so-called characteristics of Generation $Y$ employees are viewed as problematic by some employers in the hospitality industry. One reason for this is that Generation $Y$ employees perceived as having distinctive character traits, such as a lack of respect for authority and a desire for immediate gratification. They are open, rebellious, aggressive and eager to make money (Cairncross \& Buultjens, 2007; Jones, 2007).

According to Solnet and Hood (2008), one could describe Generation Y learners as demanding individuals who are not afraid to express their opinions (Earle, 2003). However, Generation Y employees tend to be less satisfied with their jobs, less engaged in their work and far less committed when it comes to the organisation they work for. Cairncross and Buultjens (2007) confirm that employers believe if Generation Ys are unhappy with their remuneration and working conditions, they will move on.

Technology-driven media offer opportunities for new forms of learning in the work and educational environment (Beham, Kump, Ley \& Lindstaedt, 2010).

For the purpose of this paper a concept procedure used in a hospitality department will be illustrated and discussed.

\section{WORK INTEGRATED LEARNING PROCESS FOLLOWED IN A HOSPITALITY DEPARTMENT}

The following process is followed by a hospitality department when placing learners in establishments for work integrated learning for a period of six months: 


\section{ORIENTATION}

Learners attend an orientation programme prior to commencing their experiential learning period in the industry.

This programme includes aspects such as: Compilation of a portfolio, an introduction to potential placements and the background of each establishment, procedures followed to be placed, as well as a discussion of rules and regulations regarding work- integrated learning placements.

Each learners attends a one-on-one consultation with a work-integrated learning facilitator. During this time the learner and facilitator peruse all documentation and discuss potential placements. If necessary, interviews can be scheduled.

\section{CONFIRMATION OF PLACEMENT}

Each establishment receives an email with a list of student names and contact numbers before the starting date of the experiential learning.

After a learner has been placed, a confirmation letter is issued to the learner with relevant information such as: Date of commencement of with experiential learning, contact person, relevant contact details and address of organisation.

\section{VISITS DURING PLACEMENT}

Each learner is visited at least once during the six-month period by a lecturer from the department. During the visit the lecturer will interview the learner as well as the supervisor. The purpose of this visit is to gain necessary information on the progress of the learner, but most importantly input from the industry that could assist in the training and development of the learner.

\section{INAL ASSESSMENT}

Learners are responsible for keeping a logbook for the six-month period, indicating the departments they work for as well as the main duties performed in these departments. Monthly rapports are signed off by the departmental supervisors. The supervisory reports keep track of the learner's progress. On completion of the work-integrated learning period, a final assignment is submitted by the learner incorporating all aspects learned during the academic and practical phases of the course. The purpose of the final assignment is to provide an opportunity for the student to reflect on the six-month work-integrated learning experience. Wang, Cai, Yang and $\mathrm{Qu}$ (2015) postulate that rethinking a completed internship is a meaningful way to make sense of an experience as well as to evaluate their willingness to work and their coping ability during the internship (Song \& Chathoth, 2011).

\section{CHALLENGES ENCOUNTERED DURING THE WORK-INTEGRATED LEARNING PROCESS}

With a Gini coefficient of 65.0, South Africa is seen as the most unequal country in the world. This inequality is experienced in the country's education system (Cosser, 2018). Not only does the country wrestle with improving the quality of education, but it also has to ensure equality and equity. A country's educational system cannot be developed in isolation from the macro- 
context within which it operates. External factors such as economic, political, demographic, geographic, social and labour issues, as well as international trends, need to be taken into consideration (Nieuwenhuis, 1997).

For the purpose of this study the authors focused on the challenges of a specific hospitality management department at a University of Technology. As facilitators of the work-integrated learning process in the department, challenges have been encountered. Learners fail to realise that work-integrated learning is an integral part of their academic programme. Providing the learner with a real-world experience as part of the tertiary education programme is to enhance employability while from a learner's perspective he/she needs to see WIL as the beginning of their career path (Tran \& Soejatminah, 2016). By demonstrating the impact of work-integrated learning, the learner will be able to make more informed decisions regarding their future in the hospitality industry (Brooks \& Youngson, 2016).

Learners do not attend the orientation programme as set out by the department, because this slows down the process of placing learners in the hospitality industry and of providing them with the best possible experience. The future employment of the learner can be impacted as unemployment is a reality in South Africa not providing the learner with the best possible work experience will limit his/her chances for future employment.

As a rule, large number of these students are first- generation students who are the first in their family to undertake tertiary education. First-generation students often experience difficulties such as: insufficient academic preparation (Tanjula, 2014, Stebleton \& Soria, 2012), lower precollege critical thinking levels, a lack of knowledge of time management, low self-esteem (Higgins, 2017), feelings of isolation (Covarrubias \& Fryberg, 2015) and little or no understanding of the world of work (Hirudayaraj, 2011).

It is also common for them to experience guilt because they have been given the opportunity to attend a tertiary institution and in doing so have surpassed their parents who did not have the same opportunity (Covarrubias \& Fryberg, 2015). Industry should take cognisance of their unique characteristics and the challenges that first-generation learners experience.

Hospitality establishments look for 'nice people', not necessarily for employees with technical skills, because technical skills still be taught but one cannot make people 'nice'. The hospitality industry is looking for potential employees with a personality and a good attitude - who will enjoy serving guests/customers (Korczynski, 2002). After having been placed in the hospitality industry a number of learners tend to develop a negative attitude towards the work-integrated learning experience. Some of the negative aspects of working in the industry are the long working hours (shifts), not receiving a stipend, unqualified supervisors responsible for the training of the learner, a poor attitude as well as behaviour of employees and management towards the learner.

This negative attitude manifests itself when learners leave the establishment within weeks after they have been placed, sometimes without informing the hospitality establishment or the department. Not only do learners harm the hard-won relationship between the tertiary institution and the industry regarding future placement, but they also jeopardise their own future by not completing their studies within the required time. 
For hospitality establishments and their management, it is important to understand the attitude of younger learners, as studies still reveal that work in the hospitality industry is not seen as a long-term career. These learners not only have to be challenged intellectually, but also creatively, innovatively as well as politically, as they need to go into the workplace with their eyes, hearts and minds open. This will inspire them to make the workplace a better place (Carnicelli \& Boluk, 2017).

\section{RECOMMENDATIONS}

The partnership between tertiary institutions and the hospitality industry needs to be reevaluated. More in-depth research on human resources development should become the focus for both the tertiary institution and the hospitality industry. A younger-generation labour force with specific characteristics and skills is emerging. This implies that the skills needed to perform duties are not necessarily the same as in the past.

Prospective work-integrated students should realise the importance of attending the orientation programme. During this time the intern employers should inform students of their expectations and provide an overview of the training they will receive during the internship period. Alumni who have completed their internships could be part of the new orientation programme during which they could share their experiences and highlight the advantages of a positive attitude during internship. Prospective work-integrated students should be aware of their responsibility for their own learning during their internship. They should realise the unique opportunity that they have to be able to enrich their own work performance which will surely improve their selfefficacy in the industry. Their ability to cope with difficult situations in a "protected" environment provides them with the confidence to embrace a career in the hospitality industry. A system could be developed for rewarding excellent performance during internship. This would motivate students to perform at their best during their work-integrated learning experience. Highperforming students should be part of an incentive programme in the organisation which would boost their self- confidence and employment prospects.

\section{CONCLUSION}

Tertiary education plays a very important role in developing and sustaining knowledge-based economies. They are responsible for generating knowledge that will support the development of innovation, which in return contributes to a country's economic growth (Guermat, Saad \& Boutifour, 2015). This knowledge cannot be created in isolation, therefore strong partnerships and collaboration between educational institutions and industry need to be established. Benefits for the tertiary institution could be gauged by the number of learners that find permanent employment after having completed their work-integrated learning successfully. A further benefit could be in the form of academic products such as publications in peer reviewed journals. Not only will there be financial benefit, but it will enhance the quality of the course content, which in return will foster a better position and reputation for the tertiary institution.

Successful work-integrated learning can be established only if the industry is committed to providing the "genuine" environment for training without the expectation of cheap labour. Without student commitment and responsibility, the work integrated period cannot fulfil its original aim of providing training in industry before taking up fulltime employment. 
A strong tertiary/industry partnership could bolster the industry's competitiveness. tertiary institutions could undertake further research to try to solve problems in industry, by training and preparing the learners before they commence the work- integrated learning segment. The benefit for the establishment will be increased in profit

\section{REFERENCES}

Bately, H. \& Woodbridge, M. 2007. Networking the Generation Y way: A discussion paper on the interconnectivity between the traditional hospitality industry and the emerging Gen $\mathrm{Y}$ workforce. Orion Observatory Issue, 2:29-35.

Beham, G., Kump, B., Ley, T. \& Lindstaedt, S. 2010. Recommending knowledgeable people in a workintegrated learning system. Procedia Computer Science, 1 (2):2783-279.

Brooks, R \& Youngson, P.L. 2016. Undergraduate work placements: An analysis of the effects on career progression. Studies in Higher Education, 41(9):1563-1578.

Cairncross, G. \& Buultjens, J. 2007. Generation $Y$ and work in the tourism and hospitality industry: Problem? What problem? Centre for Enterprise Development and Research. Occasional Paper, $9: 1-24$

Carnicelli, S \& Boluk, K. 2017. The promotion of social justice: Service learning for transformative education. Journal of Hospitality, Leisure, Sport \& Tourism Education, 1-3.

Chen, Z., Sun, H., Lam, W, Hu, Q., Huo, Y. \& Zhong, J.A. 2012. Chinese hotel employees in the smiling masks: roles of job satisfaction, burnout, and supervisory support in relationships between emotional labor and performance: The International Journal of Human Resource Management, 23(4):826-845.

Cosser, M. 2018. Differential pathways of South African students through higher education. International Journal of Educational Development, 59:100-109.

Covarrubias, R. \& Fryberg, S.A. 2015. Movin' on up (to college); First-generation college students' experiences with family achievement guilt. 21(3):420-429.

Davidson, M. \& Wang, Y. 2011. Sustainable labour practices? Hotel human resource managers' views on turnover and skill shortages. Journal of Human Resources in Hospitality and Tourism, 10(3):235-253.

Duncan, T., Scott, D.G. \& Baum, T. 2013. "The mobilities of hospitality work: An exploration of issues and debates. Annals of Tourism Research, 41:1-19.

Fleming, J., Martin, A.J. \& Hughes, H. 2009. Maximizing work integrated learning experiences through identifying graduate competencies for employability: A case study of sport studies in higher education. Asia-Pacific Journal of Cooperative Education, 10(3), 189-201.

Gorman, P., Nelson, T. \& Classman, A. 2004. The millennial generation: A strategic opportunity. Operational Analysis, 12(3):255-270. 
Guermat, C., Saad, M. \& Boutifour, Z. 2015. Special issue: University-industry interaction and new role of universities. International Journal of Technology Management \& Sustainable Development, 14(2):67-69.

Higgins, S. 2017. First-generation students in higher education. Faculty Research Day, 2017-03-24.

Hirudayaraj, M. 2011. First-generation students in higher education: Issues of employability in a knowledge-based economy. Online Journal for Workforce Education and Development, (3):1-10.

Jackson, D. 2015. Employability skill development in work-integrated learning: Barriers and best practice. Studies in Higher Education, 40(2):350-367.

Jones, P.A. 2007. The iPod and the phone: wired and mobile: Characteristics of the millennium generation. Orion. Journal of International Hotel Management, 2:11-14.

Kelli, A., Mets, T., Jonsson, L., Pisuke, H. \& Adamsoo, R. 2013. The changing approach in academiaindustry collaboration from profit orientation to innovation support. Trames, 17(67/62), 3:215-241.

Mather, C.A., McKay, A. \& Allen, P. 2015. Clinical supervisors' perspectives on delivering work integrated learning: A survey study. Nurse Education Today, 35(4):625-310.

McLennan, B. \& Keating, S. 2008. Work-integrated learning (WIL) in Australian universities: The challenges of mainstreaming WIL. Paper presented at the ALTC NAGCAS National Synopsium Melbourne, Australia.

Nieuwenhuis, F.J. 1997. Can research into the development of education in post-colonial Africa shape education policies in South Africa? International Journal Educational Development, 17(2):129-143.

Pratt, M. \& Hahn, S. 2016. Enhancing hospitality student learning through the use of a business simulation. Journal of Hospitality, Leisure, Sport \& Tourism Education, 19: 10-18.

Siu, G., Cheung, C \& Law, R. 2012. Developing a conceptual framework for measuring future career intention of hotel interns. Journal of Teaching in Travel and Tourism, 12(2):188-215.

Solnet, D. \& Hood, A. 2008. Generation Y as hospitality employees: Framing a research agenda. Journal of Hospitality and Tourism Management, 15:59-68.

Song, Z. Chathoth, P.K. 2011. Intern newcomers' global self-esteem, overall job satisfaction and choice intention: Pearson-organisation fit as mediator. International Journal of Hospitality Management, 30(1):119-128.

Stebleton, M. J. \& Soria, K. M. (2012). Breaking down barriers: Academic obstacles of first-generation students at research universities. The Learning Assistance Review, 17:7-19.

Swart, C. 2014. An assessment of work-integrated learning for public relations in an open-distance learning context. Public Relations Review, 40:387-396.

Tanjula, P. 2014. Motivating first-generation students to academic success and college completion. College Student Journal, 2:257-264.

Tran, L.T. \& Soejatminah, S. 2016. 'Get foot in the door': International students' perceptions of workintegrated learning. British Journal of Educational Studies, 64(3):337-355. 
Tsaur, S. \& Tang, Y. 2012. Job stress and well-being of female employees in hospitality: The role of regulatory leisure coping styles. International Journal of Hospitality Management, 31:1038-1044.

Tudor, S. \& Mendez, R. 2014. Lessons from Covey: Win-win principles for university-employer engagement. Higher Education, Skills and Work-based Learning, 4(3): 213-227.

Wang, Y.C., Cai, R., Yang, C.E \& Qu, H. 2015. Coping strategy in Hospitality internships: A mixed method approach. Journal of Hospitality and Tourism Education, 27:10-19.

Wessels, M. 2005. Experiential learning. Cape Town: Juta \& Co.

Zhang, B., Yin C., David, B., Xiong, Z. \& Niu, W. 2016. Facilitating professional's work-based learning with a context-aware mobile system. Science of Computer Programming, 129:3-19.

Zhou, P., Tijssen, R. \& Leydesdorff, L. 2016. University-Industry collaboration in China and the USA: A bibliometric comparison. Journal. Pone. 0165277. Plos One, 10.1371:1-18. 